便であるので，今後invivo の粉じん毒性解明に in vitro の研究が寄与するようこれらの研究の進展を切望 する.

\section{9. 京都方におけるじん肺患者の実態} 片木健一 (京都南病院) 宮入昭午 (関西労苂職業病研)

（はじめに）じん肺管理 4 決定者は全国と同樣京都に 执いても随時申請によるものがしだいに增加している。 その理由の一つとしてじん肺法等のしくみを知りえなか った人々が多かったことがあげられるであるう。今回報 告するのは京滋じん㬨患者同盟が京都南の委嘱を受壮行 なったじん肺労災受給者計 144 名の実態調査の結果（法 的に不適切な状沉が認められた 3 憘例報告もふくむ)で ある.

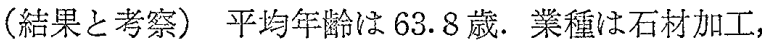
陶磁器製造，鉱内鉱物作業の順比多い，学谈補償給付月 額は平均 12.8 万円で 10 万円未満が $22.7 \%$ 存在した. その他の年金を受給している者は $64.6 \%$ であり，内訳 は厚生年金 $42.4 \%$ ，国民年金 $18.1 \%$ 等で岕る，同居家 族江有収入者がいる者は $35.4 \%$ で每る，現在の経済状 態について「多少余裕がある」は $5.8 \%$ のみであり「苦 しい」が $33.3 \%$ に達する. 現在希望していることは 「労㷋保険の余病への適用」「学㷋補償給付の充実」の 順でむった。一方「外見的に病人らしくない」等の理由 で気まずい思いを近所に䞑してもっている者は $25.7 \%$ も存在している。身障者手帳の保有率は $38.2 \%$, 随時申 請制度を知っている者は $59.7 \%$ にとどまっている，ま た，自分の管理区分を知らない者（忘れた者 13 名を含 む) 㤾 25 名 (17.4\%) 存在した.

（まとめ）比較的じん肺㭧者の㻕り特こし等の活動が 進んでいると思われる京都に叔いても多くの法的に不適 切な状況があることが一部解明でさた。 またじん肺労㷋

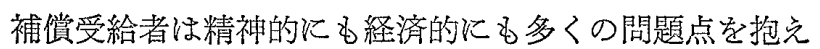
ていることがわかった．現在京都府ではじん肺患者同盟 の要請により独自にずべての粉じん作業者に手帳を交付 している. その効果については今後追跡していきたい.

250。 大分県南における出稼じん肺症に関する社会医 学的研究

畧 博, 和気健三（福岡大医公衛）

大分県南の海岸部は榢道工等を專門とする出 稼地 带 で，これに伴う健康障暂一じん肺症，振動障管等一が多 発し, 社会問題化している. 今回, 大分紧南の典型的な 出秾部落（A 浦）の地域調查を実施し，隧道工雺の出稼 へ駆り立てた社会経済的背景，じん脖管理III以下の非認 定者の実熊, 戦後に括ける隧道工事出稼の経時的変化牱
よび㯌道工事出稼に伴う健康障害が地域に及ぼす影響に ついて検討した.

結果は次のごとくである.

(1) 畑・果樹園 (2か九園) ・ 山林・漁船の保有状況 は，畑・果樹園では 89.4\%，山林では $83.7 \%$ の世帯が 0.3 ha 未淽で岕った，田を保有する世帯ふなかった。 瀂船がある世带は $22.2 \%$ であった。このようにその農

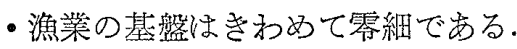

(2) 昭和 55 年時点の出稼状沉をると，A消の 15 歳 以上の男性は 115 名で, そのらら現在隧道工事の出稼に 出ているもの 21 名 (18.3\%), 隧道工事出稼の経験はあ るが，現在气れから離れているもの 21 名 (18.3\%)，じ 几肺認定者 36 名 $(31.3 \%)$ であった. 隧道工素出稼歷 を有するものは 15 歳以上の男性の $67.9 \%$ に及んでい た.

(3) じん肺症に認定されていないるののらち, 粉でん

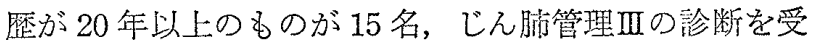
けているるのが 9 名めり, 当分じん肺認定者は增加し続 沙るものと思われる。

(4.) 隧道工事出稼の経時的変化についてみると，A浦 の出稼のピークは昭和 20 年代で, 高度経済成長期には すで出稼者の減少傾向が認められる.

(5) 30 59 藏の結婚歷の出る女性 85 名のうち, 戦 後，夫に先立たれた婦人が 10 名（11.8\%）西った. 10 名中 4 名がじん肺症焉るいは労災事故による死亡であっ た。隧道工事の出稼に伴う健康障害は出稼者自身にとど まらず，その配偶者の上にる重くのしかかっている。

251. 大分県佐伯市および南海部郡における出稼ぎじ ん肺（玨肺）について（第 5 報）

長門 宏，深田修司，松林 直

（長門莫記念会長門記念病院） 三浦 啓（佐伯保健所） 葉玉哲生（大分罧立病院） 河野友信（都立駒込病院）

(1) S35 S55年 8月末当院で要治療とされた 734 人 について悪性腫演特に肺癌について検討した。

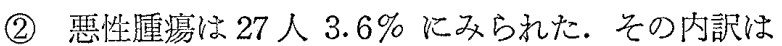
肺癌 11 例, 胃癌 5 例, 肝癌 5 例, 大腸癌 3 例, 総胆管 癌（早期胃癌術後に発生した重複癌？）1例，白血病 1

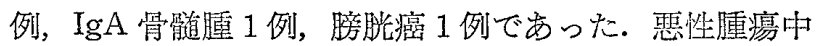
肺癌が $11 / 27$ 人 $40.7 \%$ といらばん多かった。

(3) 組蟣学的に肺癌と診断された 10 例について検討

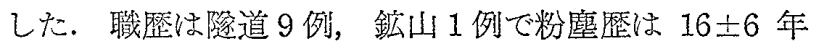
で，労災認定時年龄は 55.6 10.6 歳，医学的理由は肺 結核 9 例， $F_{3} 3$ 例で岁った。死亡は 6 例で，死亡時年 